\title{
THE JOURNAL OF BIOLOGICAL CHEMISTRY
}

Founded by Christian A. Herter and sustained in part by the Christian A. Herter Memorial Fund

EDITORIAL BOARD

RUDOLPH J. ANDERSON

W. MANSFIELD CLARK

HANS T. CLARKE

CARL F. CORI

EDWARD A. DOISY

A. BAIRD HASTINGS
HOWARD B. LEWIS

ELMER V. MCCOLLUM

WILLIAM C. ROSE

WILLIAM C. STADIE

DONALD D. VAN SLYKE

HUBERT B. VICKERY

EDITORIAL OFFICE

Sterling Tower, Yale University, Ncw Haven, Connecticut

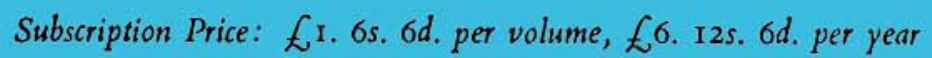

Subscriptions may be sent to the Periodical Department

BAILLIÈRE, TINDALL \& COX, 7-8 HENRIETTA ST., LONDON, W.C. 2

FULL PARTICULARS OF THE

\section{JOURNALS}

PUBLISHED BY THE

CAMBRIDGE UNIVERSITY PRESS

MAY BE HAD FROM

THE MANAGER, CAMBRIDGE UNIVERSITY PRESS

BENTLEY HOUSE, 200 EUSTON ROAD

LONDON, N.W. I 


\section{PROCEEDINGS \\ OF THE NUTRITION SOCIETY}

General editor S. K. KON

\section{PROCEEDINGS OF THE ENGLISH GROUP}

Edited by E. M. M. HUME and S. K. KoN

PROCEEDINGS OF THE SCOTTISH GROUP

Edited by E. W.'M. Cruickshank, W. M. Deans and I. Leitch

Published for The Nutrition Society by

W. Heffer \& Sons, Ltd., 3 \& 4 Petty Cury, Cambidge, England

Price: 25 s. net per volume; single numbers $7 s .6$ d. net, double numbers $15 s$. net

The Proceedings of The Nutrition Society contain a full record of papers and discussions at the Scientific meetings of the Society held from its formation in 1941 up to the end of 1946 . Volumes $1-4$, containing reports of meetings held during $1941-1945$ have been published. The first double number of Volume 5 , recording meetings heli during 1946 , is also out and the other two numbers will be published shortly. In all, reports will be available of 37 Scientific Conferences of the Society, covering a wide range of topics in most fields of Nutrition. With the completion of Volume 5, the Proceedings will cease appearing separately and will be merged in the British Journal of Nutrition, published by the Cambridge University Press.

Inquiries for Volumes 1-5 of these Proceedings should be addressed to the publishers

W. HEFFER \& SONS, LTD. 3 \& 4 PETTY CURY, CAMBRIDGE, ENGLAND 